INDEPENDENT JOURNAL OF MANAGEMENT \& PRODUCTION (IJM\&P)

http://www.ijmp.jor.br

v. 5, n. 2, February - May 2014.

ISSN: 2236-269X

DOI: 10.14807/ijmp.v5i2.156

\title{
MARKOV CHAIN PORTFOLIO LIQUIDITY OPTIMIZATION MODEL
}

Eder Oliveira Abensur

Universidade Federal do ABC (UFABC), Brazil

E-mail: eder.abensur@ufabc.edu.br

Submission: 18/10/2013

Accept: 03/11/2013

\begin{abstract}
The international financial crisis of September 2008 and May 2010 showed the importance of liquidity as an attribute to be considered in portfolio decisions. This study proposes an optimization model based on available public data, using Markov chain and Genetic Algorithms concepts as it considers the classic duality of risk versus return and incorporating liquidity costs. The work intends to propose a multicriterion non-linear optimization model using liquidity based on a Markov chain. The non-linear model was tested using Genetic Algorithms with twenty five Brazilian stocks from 2007 to 2009. The results suggest that this is an innovative development methodology and useful for developing an efficient and realistic financial portfolio, as it considers many attributes such as risk, return and liquidity.
\end{abstract}

Keywords: Portfolio Optimization, Markov chain, Genetic Algorithms 


\section{INTRODUCTION}

The fundamentals of the Modern Finance Theory are represented by articles written by Markowitz (1952) and Sharpe (1964). Markowitz broke the paradigms of portfolio selection that considered only the return aspect. His proposed formulation based on the risk-return duality, explains why diversification is an advantage when it comes to portfolio selection and demonstrates that there is an optimal mix of assets in a portfolio that achieves both maximum return with a minimum risk.

Markowitz formulated the variance (or risk) theory of a generic portfolio composed of $n$ assets and showed that it depends on the variances of individual assets and the covariance's between pairs of assets involved, as originally published in the following formula:

$$
V=\sum_{i=1}^{n} \sum_{j=1}^{n} \sigma_{i j} X_{i} X_{j}
$$

Where:

$X=$ asset participation in the portfolio

$\sigma_{i j}=$ covariance between asset $i$ and asset $j$

$n=$ number of assets

Sharpe (1964) developed the fundamentals of asset pricing by taking into account the conclusions of Markowitz portfolio risk. Among its conclusions, he emphasizes that there is a linear relationship between the rates of return on assets and their covariance with the market portfolio. This relationship is expressed by beta $(\beta)$, a standardized covariance to the market portfolio variance. Therefore, there is a linear relationship between the return on assets and $\beta$ defined by:

$\bar{R}=R_{F}+\beta\left(R_{M}-R_{F}\right)$

Where:

$$
\begin{aligned}
& \bar{R}=\text { asset expected return } \\
& R_{F}=\text { risk-free rate } \\
& \beta=\text { beta of the asset }
\end{aligned}
$$


INDEPENDENT JOURNAL OF MANAGEMENT \& PRODUCTION (IJM\&P)

http://www.ijmp.jor.br

v. 5, n. 2, February - May 2014.

ISSN: 2236-269X

DOI: 10.14807/ijmp.v5i2.156

$R_{M}=$ market expected return

According to the Modern Portfolio Theory, the risk of a portfolio can be divided into two components: (i) a factor that affects a large number of assets, each with a higher or lower intensity, called systematic and (ii) a factor that specifically affects a single asset or a small group of assets, called unsystematic or specific (ROSS; WESTERFIELD; JAFFE, 1999).

Also, according to the Modern Portfolio Theory, the relevant profitability differences can only be explained by systematic and unsystematic risks. Any premium, representing an undesirable feature of the asset would be explained by a premium of unsystematic risk. Finding a premium that is represented by a factor not related to unsystematic risk represents an anomaly in the theoretical model. The literature presents a vast collection of discussions on possible anomalies to the basic model such as Banz (1981), Fama and French (1992), Heston and Sadka (2008), Hogan (2004) and Lewellen (2006) among others.

Over time, other operational and conceptual problems have been identified in the original formulation of Markowitz. The most important are:

a) There are computational difficulties related to solving large-scale quadratic programming problems (KONNO; YAMAZAKI, 1991; YOUNG, 1998; PARRA et al., 2001);

b) Generally, the portfolios obtained by the original formulation concentrate on few assets, which is against the idea of diversification (JANA et al., 2009);

c) The absence of transaction costs and liquidity (or illiquidity) can result in inefficient portfolios (ARNOTT; WAGNER, 1990; AMIHUD; MENDELSON, 1991);

d) In large portfolios the model would suggest the purchase of a small fraction of assets, often lower than the minimum traded in the market (KONNO; YAMAZAKI, 1991);

e) The resolution of the quadratic programming model is intractable for entire portfolios with more than 20 assets (KONNO; YAMAZAKI, 1991); 
INDEPENDENT JOURNAL OF MANAGEMENT \& PRODUCTION (IJM\&P)

http://www.ijmp.jor.br

v. 5, n. 2, February - May 2014.

ISSN: 2236-269X

DOI: 10.14807/ijmp.v5i2.156

f) The model assumes there are no difficulties in liquidating the portfolio formed, in other words, the market would absorb any type and amount of assets allocated by optimization (POGUE, 1970).

This study does not intend to discuss liquidity from the perspective of an anomaly, in accordance with the Modern Portfolio Theory. However, it is a fact that liquidity or transaction costs are implicitly incorporated by investors in their investment allocation decisions. In other words, all else being equally constant, investors prefer more liquid than less liquid assets, particularly in the short-term.

Recently there has been an increased interest in studies of financial models with parameters modulated by Markov chains in an attempt to reflect the dynamics of the markets under conditions of financial distress (BAUERLE; RIEDER, 2004; CAKMAK; OZEKICI, 2006; COSTA; ARAUJO, 2008; REBOREDO, 2002). Liquidity would be one more attribute of any investments allocation decision, expanding investor focus beyond the traditional duality of risk vs. return.

The work is structured as follows: (i) section 2 describes the methodology of the research; (ii) section 3 presents several ways to measure liquidity, presents empirical evidence on the adopted liquidity indicator and proposes a measure of liquidity for the portfolio based on Markov chain concepts; (iii) section 4 shows the Markowitz model; (iv) section 5 shows the proposed model; (v) in section 6, the tests applied are characterized and the results presented and (vi) section 7 presents the conclusions of the study.

\section{METHODOLOGY}

This paper is an experimental research evaluation, also involves the use of standardized techniques of data collection and simulation.

The job data were collected from daily reports provided by the BMF\&Bovespa from January 2007 to September 2009. The selection, comparison and testing of hypotheses applied to the chosen liquidity indicator comprised the years 2007 and 2008. To perform the simulations, an application based on an Excel spreadsheet using the Microsoft Excel® nonlinear programming solver for the Markowitz model was developed. The proposed model used the search tool Evolver ${ }^{\circledR}$ with Genetic Algorithms. Portfolios were formed and compared from an arbitrary initial application 
INDEPENDENT JOURNAL OF MANAGEMENT \& PRODUCTION (IJM\&P)

of $\$ 5,000$, before Brazilian taxes. The estimated price of these shares was based on the average behavior of the Brazilian financial market in the first half of 2009.

Liquidity was estimated by weighting the frequency $F$ obtained by dividing the trading days of each action in period $\left(F_{a}\right)$ by the number of trading days in the period $\left(F_{p}\right)\left(F=F_{a} / F_{p}\right)$. This frequency was weighted by its respective average $I N$ divided by the maximum number recorded between the studied securities $\left(F \times I N_{\text {avg }} / I N_{\text {max }}\right)$ ). The weighted ratio was grouped into quartiles arbitrarily assuming, the average probability of $1,2,3$ and 4 , respectively, $1.00,0.75,0.50$ and 0.05 . This was the possible liquidity estimate that could be obtained from the public data available. The proposed liquid measure was incorporated in a stochastic process of Markov chain in order to evaluate the probability of trading the shares.

\section{LIQUIDITY MEASURES}

The concept of liquidity can be found in many ways. In accounting, liquidity is associated with the ease or speed which an asset can be turned into cash. In economic terms, an asset is considered liquid if its value is both easily negotiable and experiences little volatility over time.

In financial terms, liquidity can be defined as the ease which an asset can be exchanged within a short period of time (trading) without causing significant changes in its price (transaction cost). It is a systemic phenomenon that depends on the interaction between economic agents, where one wants to buy the asset (tangible or intangible) from another.

For purposes of this study, among the measures selected and analyzed were the known liquidity indicators highlighted in literature and market practices as follows: (i) liquidity-based on spread, (ii) liquidity based on impact on the price, (iii) liquidity based on frequency and (iv) hybrids, liquidity based on a combination of two or more factors. Table 1 below summarizes these indicators.

The indicators in Table 1 were divided according to the type of approach, but they can also be classified according to their data collection frequency. Intraday indicators are generate over a short period of time during the trading session (eg: bid ask spread, effective spread) and others can be collected on a daily, monthly, quarterly or yearly basis (e.g.: Roll, Holden, Zeros, Amihud). Moreover, intraday indicators can be converted into higher frequencies (bid ask spread). Intraday 
indicators are not available to the public, so the question is whether the low frequency indicators can be used. Goyenco, Holden and Trzcinka (2009), concluded that low frequency indicators provide good liquidity measures.

Table 1 - Analyzed liquidity measures

\begin{tabular}{|c|c|c|c|c|}
\hline Measue & Type & Description & Formula & \\
\hline $\begin{array}{l}\text { Bid-ask } \\
\text { spread }\end{array}$ & spread & $\begin{array}{l}\text { Difference between the } \\
\text { best selling and buying } \\
\text { offers divided by the } \\
\text { average price }\end{array}$ & $\frac{\text { Ask }- \text { Bid }}{(A s k+B i d)_{2}}$ & (3) \\
\hline Roll & spread & $\begin{array}{l}\text { Assesses the effective } \\
\text { spread based on price } \\
\text { covariance }\end{array}$ & $\begin{cases}\left.2 \sqrt{-\operatorname{Cov} \Delta P_{t, \Delta P_{t-1}}}\right) & \left.\text { when } \operatorname{Cov} \Delta P_{t, \Delta P_{t-1}}\right)<0 \\
0 & \text { when } \operatorname{Cov}\left(\Delta P_{t, \Delta P_{t-1}}\right) \geq 0\end{cases}$ & \}$(4)$ \\
\hline $\begin{array}{l}\text { Effective } \\
\text { tick }\end{array}$ & spread & $\begin{array}{l}\text { Assesses the weighted } \\
\text { spread probability divided } \\
\text { by the average }\end{array}$ & $\frac{\sum_{j=1}^{J} \gamma_{j} \mathcal{S}_{j}}{P_{i}}$ & (5) \\
\hline Holden & spread & $\begin{array}{l}\text { Weighted average of } \\
\text { possible spreads }\end{array}$ & $\sum_{j=1}^{J} \gamma_{j} S_{j}$ & (6) \\
\hline LOT & spread & $\begin{array}{l}\text { Difference between } \\
\text { percentage costs of buying } \\
\text { and selling }\end{array}$ & $\alpha_{j 2}-\alpha_{j 1}$ & (7) \\
\hline Zeros & spread & $\begin{array}{l}\text { Percentage of days with } \\
\text { zero return }\end{array}$ & $\frac{\# \text { days with } 0 \text { return }}{T(\# \text { trading days })}$ & (8) \\
\hline Amihud & price & $\begin{array}{l}\text { Ratio of the return of a } \\
\text { share and its financial } \\
\text { volume }\end{array}$ & $\operatorname{avg}\left(\frac{\left|r_{t}\right|}{\text { Volum }_{t}}\right)$ & (9) \\
\hline Amivest & price & $\begin{array}{l}\text { Ratio of the financial } \\
\text { volume of a share and its } \\
\text { return }\end{array}$ & $\operatorname{avg}\left(\frac{\text { Volum }_{t}}{\left|r_{t}\right|}\right)$ & (10) \\
\hline Turnover & frequency & $\begin{array}{l}\text { Ratio of the daily financial } \\
\text { traded share and the } \\
\text { number of outstanding } \\
\text { shares }\end{array}$ & $\frac{1}{D_{Q}} \sum_{t=1}^{Q} \frac{\text { volum }_{t}}{\text { outstanding stocks }}$ & (11) \\
\hline$I N^{1}$ & hybrid & $\begin{array}{l}\text { Measures the negotiation } \\
\text { intensity of a share } \\
\text { combining the number } \\
\text { negotiate ratio }(n / N) \text { with its } \\
\text { financial volume ratio }(v / V)\end{array}$ & $\sqrt{\frac{n}{N} \times \frac{v}{V}}$ & (12) \\
\hline$I N_{p}^{2}$ & hybrid & $\begin{array}{l}\text { Combines the IN of a share } \\
\text { with its stock exchange } \\
\text { frequency floor }\end{array}$ & $\frac{\text { \# stock trading days }}{\# \text { trading days }}$ & (13) \\
\hline
\end{tabular}

Source: Lesmond (2005), Goyenco, Holden and Trzcinka (2009)

${ }^{1}$ Liquidity measure used in the Brazilian financial market (PAULA LEITE and SANVICENTE, 1995; BMF\&Bovespa, 2012)

${ }^{2}$ Liquidity measure proposed to evaluate trading probability of the formed portfolio

The Brazilian stock market releases and offers the public daily information on the bid-ask spread for each traded stock and releases the necessary data to evaluate the negotiability index $(I N)$. The IN has several advantages: (i) available data; (ii) 
INDEPENDENT JOURNAL OF MANAGEMENT \& PRODUCTION (IJM\&P)

reliability because the data come from the BMF\&Bovespa; (iii) measuring the intensity of trading action is consistent with the purposes of this study and (iv) by assessing the quantity and total financial volume traded in a period of time, IN avoids price distortion in the analysis of a long time series, for example, cases of split and bonus. However, IN does not assess the exposure frequency of the stock during the analyzed period.

Due to the facts presented, a new liquidity ratio $\left(I N_{P}\right)$ was proposed whose calculation method is shown in Table 1.

\subsection{Empirical Evidences of the Adopted Liquidity Measure $\left(I N_{P}\right)$}

It is now of interest to test the validity of some the predictable behaviors expected from the definitions and characteristics of the liquidity measure adopted for asset classification $\left(I N_{P}\right)$. In particular, it is expected that there is independence between the $I N_{P}$ of the analyzed assets. If this does not happen, in other words, if there are any assets that might lead to dependence on trading then these assets will be identified and other stocks should be negotiated after them.

Among the 420 listed shares on Bovespa, three groups were formed representing high, medium and low trading activity (liquidity) in accordance with the $I N_{P}$ and current rules of the Brazilian stock market. The stratified collection of data was carried out according to the historical financial information published by Bovespa. The highly traded group of shares (group 1), called blue chips, were randomly selected into a group of 12 stocks that represent $40 \%$ of Bovespa.

Intermediately traded stocks (group 2) were randomized into a group of 10 that have a $6 \%$ share of the total market. According to the same sources, the selected stocks in the group with low liquidity (group 3) represent 7 stocks that account for less than $0.05 \%$ of total Brazilian market. The rates for the groups were collected from the Daily Bulletin of Business of BMF\&Bovespa over a period of 494 consecutive trading days in 2007 and 2008 or 24 months. This period comprised various typical aspects of business life such as tender offers, acquisitions, mergers, splits, bonuses, equity contributions, disclosure of half-yearly results and disclosure of relevant facts. In addition to the above criteria, the following conditions for the formation of groups were used:

a) Companies in the process of reorganization or bankruptcy were excluded;

b) Companies bought or merged during the period of analysis were excluded; 
INDEPENDENT JOURNAL OF MANAGEMENT \& PRODUCTION (IJM\&P)

http://www.ijmp.jor.br

v. 5, n. 2, February - May 2014.

ISSN: 2236-269X

DOI: 10.14807/ijmp.v5i2.156

c) Companies with less than 12 months of participation in BMF\&Bovespa were excluded;

d) The shares were selected exclusively by liquidity.

Although the samples were stratified, the active components of each group were randomly selected which allowed for the formation of a diversified group consisting of common shares (ON) and preferred shares (PN) in several areas of activity such as: the food and beverage industry, ceramic industry, garment industry, metallurgical industry, petroleum industry, financial institutions, energy companies, steel companies, telecommunication companies, hotels, wholesalers of pharmaceutical products, insurance companies and construction companies.

The null hypothesis $(\mathrm{HO})$ of there being no significant correlation between assets was formulated. Evaluations were conducted on the cross-correlations between assets of different groups, and between assets of the same group. The identification of companies and the results of the correlation analysis on $I N_{P}$ are shown in Tables 2 to 13.

Table $2-I N_{p}$ correlation between highly liquid assets in 2007

\begin{tabular}{|l|c|c|c|c|c|c|c|c|c|c|c|}
\hline & Ambev & Bradesco & B. Brasil & Gerdau & Itaú & Net & Petrobras & CSN & Telemar & Usiminas & Vale \\
\hline Ambev & - & $0,2011^{*}$ & 0,1216 & $0,2111^{*}$ & $0,2858^{*}$ & $0,2048^{*}$ & $0,2413^{*}$ & $0,1770^{*}$ & $0,2350^{*}$ & 0,0568 & $0,1839^{*}$ \\
Bradesco & & - & 0,1439 & 0,1359 & $0,1714^{*}$ & $0,4132^{*}$ & $0,2063^{*}$ & 0,0819 & $0,2702^{*}$ & 0,0827 & 0,0419 \\
B. Brasil & & & - & 0,0835 & 0,0754 & $0,1759^{*}$ & 0,1238 & 0,0485 & 0,0188 & $-0,0026$ & $-0,0558$ \\
Gerdau & & & & - & $0,1862^{*}$ & 0,0873 & 0,0186 & 0,1132 & 0,0934 & $0,1719^{*}$ & 0,3301 \\
Itaú & & & & & - & 0,0860 & 0,1489 & 0,1288 & 0,0710 & 0,1332 & 0,1596 \\
Net & & & & & & - & $0,2883^{*}$ & $-0,0229$ & $0,2886^{*}$ & 0,0426 & 0,0716 \\
Petrobras & & & & & & & - & 0,0498 & $0,1949^{*}$ & 0,0463 & 0,0688 \\
CSN & & & & & & & & - & 0,0533 & $0,3187^{*}$ & 0,0907 \\
Telemar & & & & & & & & & - & 0,0374 & 0,1045 \\
Usiminas & & & & & & & & & & - & 0,0667 \\
Vale & & & & & & & & & & & \\
\hline
\end{tabular}

*denotes significance at the $1 \%$ level

Table $3-I N_{p}$ correlation between moderately liquid assets in 2007

\begin{tabular}{|c|c|c|c|c|c|c|c|c|c|c|}
\hline & Comgás & TAM & MMX & Celesc & $\mathrm{OHL}$ & Porto Seguro & Randon & Copasa & Marcopolo & Klabin \\
\hline Comgás & - & 0,0475 & $-0,1403$ & $0,2544^{*}$ & $-0,0238$ & 0,1269 & $0,1710^{*}$ & $-0,0323$ & $-0,0032$ & $0,2418^{*}$ \\
\hline TAM & & - & $-0,1340^{+}$ & $0,1903^{*}$ & 0,0062 & 0,0827 & 0,0853 & $-0,0082$ & 0,0195 & $0,2120^{*}$ \\
\hline MMX & & & - & $-0,1843^{*}$ & $-0,0620$ & $-0,0647$ & $-0,1446$ & 0,0270 & 0,0790 & $-0,1091$ \\
\hline Celesc & & & & - & $-0,0123$ & 0,0726 & 0,1196 & 0,0610 & $-0,0435$ & 0,2569 \\
\hline $\mathrm{OHL}$ & & & & & - & $-0,0196$ & 0,0632 & $-0,0289$ & $-0,0027$ & $-0,0327$ \\
\hline Porto Seguro & & & & & & - & $0,2770^{*}$ & 0,0165 & $-0,0617$ & 0,2548 \\
\hline Randon & & & & & & & - & 0,1396 & 0,0875 & $0,1688^{*}$ \\
\hline Copasa & & & & & & & & - & 0,1424 & $0,1638^{*}$ \\
\hline Marcopolo & & & & & & & & & - & 0,0908 \\
\hline Klabin & & & & & & & & & & - \\
\hline
\end{tabular}


INDEPENDENT JOURNAL OF MANAGEMENT \& PRODUCTION (IJM\&P)

http://www.ijmp.jor.br

v. 5, n. 2, February - May 2014.

ISSN: $2236-269 X$

DOI: 10.14807/ijmp.v5i2.156

Table $4-I N_{p}$ correlation between assets with low liquidity in 2007

\begin{tabular}{|l|c|c|c|c|c|c|c|}
\hline & Caf Brasilia PN & Sergen PN & Tupy ON & Excelsior PN & Hercules PN & Hoteis Otton & Marisol PN \\
\hline Caf Brasília PN & - & $-0,0019$ & 0,2728 & 0,0076 & 0,0903 & 0,0657 & 0,0346 \\
Sergen PN & & - & $-0,0540$ & $-0,0419$ & 0,0316 & $-0,1345$ & $-0,0329$ \\
Tupy ON & & & - & 0,1722 & 0,0606 & $-0,1590$ & 0,0929 \\
Excelsior PN & & & & - & $-0,0018$ & $-0,1432$ & 0,0805 \\
Hercules PN & & & & & - & $-0,0579$ & 0,0691 \\
Hoteis Otton & & & & & & - & $-0,0812$ \\
Marisol PN & & & & & & & - \\
\hline
\end{tabular}

${ }^{*}$ denotes significance at the $1 \%$ level

Table 5 - IN $N_{p}$ correlation between highly and moderately liquid assets in 2007

\begin{tabular}{|c|c|c|c|c|c|c|c|c|c|c|}
\hline & Comgás & TAM & MMX & Celesc & $\mathrm{OHL}$ & Porto Seguro & Randon & Copasa & Marcopolo & Klabin \\
\hline Ambev & 0,0801 & $-0,0462$ & 0,0775 & $-0,0016$ & $-0,0748$ & $-0,0057$ & $-0,0357$ & 0,0567 & 0,0449 & 0,0172 \\
\hline B. Brasil & $-0,0413$ & $-0,1252$ & $0,1887^{*}$ & $-0,3092^{*}$ & $-0,1382$ & $-0,0451$ & $-0,1071$ & $-0,0288$ & $-0,0317$ & $-0,1742^{*}$ \\
\hline Gerdau & 0,1215 & $-0,0818$ & 0,0532 & 0,0330 & 0,0214 & 0,0965 & 0,1593 & 0,0857 & $-0,0785$ & 0,1381 \\
\hline Net & 0,1150 & 0,0379 & 0,0429 & 0,0398 & $-0,0320$ & 0,1455 & 0,0535 & $-0,0197$ & $-0,1074$ & $0,2551^{*}$ \\
\hline Petrobras & $-0,1330$ & $-0,0861$ & 0,0054 & $-0,0261$ & 0,1497 & 0,0542 & $-0,0138$ & $-0,1081$ & $-0,1452$ & $-0,0046$ \\
\hline Usiminas & $0,2133^{*}$ & 0,1140 & $-0,1352$ & $0,3113^{*}$ & $-0,1072$ & $0,1682^{*}$ & $0,1953^{*}$ & 0,0673 & $-0,1139$ & $0,2092^{*}$ \\
\hline Vale & $-0,1973^{*}$ & $-0,2235^{*}$ & $0,1667^{*}$ & $-0,2359^{*}$ & $-0,0009$ & $-0,0488$ & $-0,0958$ & 0,1002 & 0,0405 & $-0,1819^{*}$ \\
\hline
\end{tabular}

*denotes significance at the $1 \%$ level

Table 6 - INp correlation between assets with high and low liquidity in 2007

\begin{tabular}{|l|c|c|c|c|c|c|c|}
\hline & Caf Brasília PN & Sergen PN & Tupy ON & Excelsior PN & Hercules PN & Hoteis Otton & Marisol PN \\
\hline Ambev & 0,1312 & 0,1295 & $0,3559^{*}$ & $-0,0096$ & 0,1143 & $-0,1180$ & 0,1388 \\
Bradesco & 0,0038 & $-0,0233$ & $-0,0619$ & $-0,0453$ & $0,1633^{+}$ & $-0,2021$ & 0,0082 \\
B. Brasil & 0,1089 & $-0,0853$ & 0,0508 & $-0,0412$ & 0,0385 & $-0,0372$ & 0,1498 \\
CESP & $-0,0101$ & $-0,0662$ & 0,0068 & 0,0878 & 0,0931 & $-0,1161$ & 0,0444 \\
Gerdau & 0,0275 & 0,0335 & 0,0151 & $-0,1637$ & 0,0270 & 0,0795 & $-0,1241$ \\
Net & 0,0497 & 0,0959 & $-0,1250$ & $-0,1152$ & $-0,0503$ & $-0,0385$ & $-0,0515$ \\
Petrobras & $-0,0432$ & 0,0923 & 0,0480 & $-0,1299$ & $-0,0022$ & $-0,0346$ & $-0,1986^{*}$ \\
CSN & $-0,0099$ & $-0,0913$ & $-0,2913$ & $-0,0904$ & $-0,0798$ & $-0,0269$ & $-0,0264$ \\
Telemar & 0,0629 & $0,2078^{*}$ & 0,1722 & $0,2196^{*}$ & 0,0148 & $-0,1939^{*}$ & 0,1691 \\
Usiminas & $-0,0777$ & 0,0354 & $-0,2117$ & 0,0217 & $-0,0499$ & $-0,0910$ & 0,0011 \\
Vale & $-0,0880$ & $-0,0534$ & $-0,2549$ & $-0,0920$ & $-0,1552$ & 0,1542 & $-0,1967^{*}$ \\
\hline
\end{tabular}

${ }^{*}$ denotes significance at the $1 \%$ level

Table 7 - INp correlation between assets with medium and low liquidity in 2007

\begin{tabular}{|l|c|c|c|c|c|c|c|}
\hline & Caf Brasília PN & Sergen PN & Tupy ON & Excelsior PN & Hercules PN & Hoteis Otton & Marisol PN \\
\hline Comgás & $0,2862^{*}$ & 0,1501 & 0,1627 & $-0,0637$ & 0,0988 & $-0,0397$ & $0,3403^{*}$ \\
TAM & $-0,0284$ & $-0,0552$ & $-0,0806$ & $-0,0224$ & 0,0089 & $-0,0721$ & 0,1655 \\
MMX & 0,1575 & $-0,1620$ & $-0,0781$ & $-0,0419$ & 0,0430 & 0,0510 & 0,0107 \\
Celesc & 0,0636 & 0,0743 & 0,0555 & 0,0669 & $-0,0588$ & $-0,1716$ & $-0,0666$ \\
OHL & $-0,0259$ & $-0,0894$ & 0,1264 & $-0,0448$ & 0,0365 & $0,5544^{*}$ & $-0,0428$ \\
Porto Seguro & $-0,0582$ & $0,2565^{*}$ & $-0,1728$ & $-0,0472$ & $-0,045$ & $-0,1247$ & $-0,0476$ \\
Randon & 0,0282 & 0,1026 & $-0,1320$ & 0,0919 & 0,0310 & 0,0350 & 0,0686 \\
Copasa & $-0,0593$ & $-0,2954$ & 0,0260 & 0,1630 & $-0,0403$ & $-0,1115$ & $-0,0470$ \\
Marcopolo & $-0,0355$ & $-0,0252$ & $-0,0979$ & $-0,0110$ & 0,0263 & $-0,0784$ & $-0,0265$ \\
Klabin & $-0,0023$ & $0,2490^{*}$ & 0,2968 & 0,0909 & 0,0060 & $-0,1395$ & $-0,0205$ \\
\hline
\end{tabular}

*denotes significance at the $1 \%$ level 
INDEPENDENT JOURNAL OF MANAGEMENT \& PRODUCTION (IJM\&P)

http://www.ijmp.jor.br

v. 5, n. 2, February - May 2014.

ISSN: 2236-269X

DOI: 10.14807/ijmp.v5i2.156

Table $8-I N_{p}$ correlation between highly liquid assets in 2008

\begin{tabular}{|l|c|c|c|c|c|c|c|c|c|c|c|}
\hline & Ambev & Bradesco & B. Brasil & CESP & Gerdau & Net & Petrobras & CSN & Telemar & Usiminas & Vale \\
\hline Ambev & - & $0,2264^{*}$ & 0,0237 & $-0,0595$ & $-0,0001$ & $-0,2068^{*}$ & 0,1487 & $-0,1211$ & 0,1038 & $-0,1247^{+}$ & $-0,1425$ \\
Bradesco & & - & $0,1978^{*}$ & $-0,1303$ & 0,0105 & $-0,1406$ & $-0,0041$ & $-0,0228$ & 0,0625 & $-0,0315$ & $-0,0312$ \\
B. Brasil & & & - & $0,2192^{*}$ & $-0,0714$ & 0,1149 & $-0,1888^{*}$ & $-0,1336$ & $-0,0314$ & $-0,1681^{*}$ & $-0,1181$ \\
CESP & & & & - & $-0,3128^{*}$ & $0,2986^{*}$ & $-0,2277^{*}$ & $-0,1734^{*}$ & $-0,1614$ & $-0,0400$ & 0,0777 \\
Gerdau & & & & & - & $-0,2311^{*}$ & $-0,0296$ & $0,3598^{*}$ & 0,1423 & 0,0622 & $-0,0581$ \\
Net & & & & & & - & $-0,2276^{*}$ & $-0,0638$ & $-0,1310$ & 0,0795 & 0,0336 \\
Petrobras & & & & & & & - & $-0,2179^{*}$ & $-0,1413$ & $-0,0917$ & $-0,1265$ \\
CSN & & & & & & & & - & $-0,0052$ & $0,3123^{*}$ & 0,0570 \\
Telemar & & & & & & & & & - & 0,0108 & $-0,0747$ \\
Usiminas & & & & & & & & & & $-0,0085$ \\
Vale & & & & & & & & & & & \\
\hline
\end{tabular}

${ }^{*}$ denotes significance at the $1 \%$ level

Table $9-I N_{p}$ correlation between moderately liquid assets in 2008

\begin{tabular}{|l|c|c|c|c|c|c|c|c|c|c|}
\hline & Comgás & TAM & MMX & Celesc & OHL & Porto Seguro & Randon & Copasa & Marcopolo & Klabin \\
\hline Comgás & - & $0,1851^{*}$ & $-0,0755$ & $0,1965^{*}$ & 0,0651 & $0,1890^{*}$ & 0,0116 & 0,0651 & $-0,0409$ & $0,2198^{*}$ \\
TAM & & - & 0,0291 & $0,2159^{*}$ & $-0,0329$ & $-0,0110$ & $-0,1130$ & 0,0688 & $-0,0047$ & $0,2092^{*}$ \\
MMX & & & - & 0,0555 & 0,0422 & $-0,1754^{*}$ & $-0,0866$ & 0,0462 & $-0,2322^{*}$ & $-0,0583$ \\
Celesc & & & & - & $-0,0831$ & $-0,0442$ & $-0,1012$ & $-0,0290$ & $-0,0758$ & $0,1778^{*}$ \\
OHL & & & & & - & 0,1026 & $0,1655^{*}$ & 0,1215 & $-0,0275$ & 0,0474 \\
Porto Seguro & & & & & & - & 0,1533 & 0,0236 & $0,1618^{*}$ & 0,1209 \\
Randon & & & & & & & - & $-0,0386$ & $0,2189^{*}$ & $-0,0945$ \\
Copasa & & & & & & & & - & $-0,0807$ & 0,1007 \\
Marcopolo & & & & & & & & & - & $-0,1071$ \\
Klabin & & & & & & & & & & \\
\hline
\end{tabular}

*denotes significance at the $1 \%$ level

Table $10-I N_{p}$ correlation between assets with low liquidity in 2008

\begin{tabular}{|l|c|c|c|c|c|c|c|}
\hline & Caf Brasília PN & Sergen PN & Tupy ON & Excelsior PN & Hercules PN & Hoteis Otton & Marisol PN \\
\hline Caf Brasília PN & - & $0,4876^{*}$ & $-0,1680$ & 0,0419 & $-0,0343$ & $0,3027^{*}$ & $-0,0182$ \\
Sergen PN & & - & 0,0848 & 0,0992 & $-0,0550$ & 0,0659 & $-0,0658$ \\
Tupy ON & & & - & $-0,2550$ & 0,2431 & $0,4895^{*}$ & $-0,0863$ \\
Excelsior PN & & & & - & 0,0018 & 0,1214 & 0,5575 \\
Hercules PN & & & & & - & $0,1786^{*}$ & 0,0343 \\
Hoteis Otton & & & & & & - & 0,0204 \\
Marisol PN & & & & & & & - \\
\hline
\end{tabular}

*denotes significance at the $1 \%$ level

Table $11-I N_{p}$ correlation between assets with high and medium liquidity in 2008

\begin{tabular}{|c|c|c|c|c|c|c|c|c|c|c|}
\hline & Comgás & TAM & MMX & Celesc & $\mathrm{OHL}$ & Porto Seguro & Randon & Copasa & Marcopolo & Klabin \\
\hline Ambev & $-0,0834$ & $-0,1528$ & 0,0381 & $-0,0033$ & $-0,0891$ & \begin{tabular}{|l|}
$-0,0631$ \\
\end{tabular} & $-0,0805$ & $-0,0139$ & $-0,1136$ & $-0,0827$ \\
\hline Bradesco & $-0,0796$ & $-0,2153^{*}$ & $-0,0803$ & $-0,0549$ & 0,0712 & $-0,0425$ & 0,0511 & $-0,0477$ & $-0,0546$ & $-0,0365$ \\
\hline B. Brasil & $-0,0572$ & $-0,1504$ & 0,0634 & $-0,0912$ & 0,0351 & 0,0572 & $0,2901^{*}$ & $-0,0277$ & 0,1442 & $-0,0021$ \\
\hline CESP & 0,0434 & 0,1350 & $-0,1909^{*}$ & 0,0779 & 0,0742 & $0,2549^{*}$ & $0,2703^{*}$ & $-0,0433$ & $0,1758^{*}$ & $-0,0057$ \\
\hline Gerdau & $-0,0269$ & $-0,0214$ & $0,1766^{*}$ & 0,0692 & $-0,1379$ & $-0,2004^{*}$ & $-0,1396$ & 0,0085 & $-0,1697^{\star}$ & 0,0494 \\
\hline Net & 0,0641 & 0,0556 & $-0,1449$ & $-0,0273$ & $0,2991^{*}$ & $0,2308^{*}$ & 0,1349 & $-0,0455$ & $0,2284^{*}$ & $-0,0804$ \\
\hline Petrobras & $-0,2379^{*}$ & $-0,2341^{*}$ & $-0,0557$ & $-0,1385$ & $-0,1823^{*}$ & $-0,1465$ & $-0,0786$ & $-0,0435$ & $-0,2283^{*}$ & $-0,2719^{*}$ \\
\hline $\mathrm{CSN}$ & $-0,0190$ & 0,0907 & $0,1898^{*}$ & $-0,0633$ & 0,0581 & $-0,1305$ & $-0,1$ & & $-0, C$ & $-0,0115$ \\
\hline Telemar & 0,0339 & 0,0999 & $0,2027^{*}$ & $0,1653^{*}$ & $-0,1614$ & $-0,0451$ & $-0,1331$ & $-0,0168$ & $-0,0482$ & 0,1777 \\
\hline Usiminas & 0,1067 & $0,1773^{*}$ & $-0,0241$ & $-0,0143$ & 0,1189 & $-0,0114$ & 0,0183 & $-0,0232$ & 0,1025 & 0,0060 \\
\hline Vale & $-0,0322$ & 0,1199 & $-0,0030$ & $-0,0392$ & 0,0134 & $-0,1433$ & $-0,0066$ & $-0,1108$ & 0,0703 & $-0,0403$ \\
\hline
\end{tabular}

*denotes significance at the $1 \%$ level 
Table $12-I N_{p}$ correlation between assets with high and low liquidity in 2008

\begin{tabular}{|l|c|c|c|c|c|c|c|}
\hline & Caf Brasília PN & Sergen PN & Tupy ON & Excelsior PN & Hercules PN & Hoteis Otton & Marisol PN \\
\hline Ambev & $-0,1431$ & $-0,2062$ & 0,1559 & $-0,0843$ & $0,1997^{*}$ & 0,0424 & 0,0391 \\
Bradesco & $-0,1519$ & $-0,2806^{*}$ & $-0,0752$ & $-0,1426$ & $-0,0523$ & $-0,2292^{*}$ & $-0,0915$ \\
B. Brasil & 0,0668 & 0,0053 & 0,0594 & $-0,0087$ & $-0,0996$ & $-0,0721$ & $-0,0890$ \\
CESP & 0,1464 & 0,1143 & $-0,4250$ & $0,2275^{*}$ & $-0,0049$ & $0,1550^{\dagger}$ & 0,0198 \\
Gerdau & $-0,0801$ & 0,0662 & 0,2259 & $-0,1966^{*}$ & $0,3298^{*}$ & $-0,1894^{*}$ & $-0,1332$ \\
Net & 0,1023 & 0,0527 & 0,0304 & 0,0964 & $-0,0430$ & 0,1523 & 0,0583 \\
Petrobras & $-0,1341$ & $-0,1375$ & 0,2887 & $-0,0816$ & 0,0315 & $-0,0947$ & $-0,0350$ \\
CSN & 0,0670 & 0,1929 & $-0,3710$ & $-0,1218$ & $-0,0482$ & $-0,1415$ & $-0,1305$ \\
Telemar & $-0,0796$ & $-0,1355$ & 0,3409 & $-0,1934^{*}$ & $-0,1139$ & $-0,1106$ & $-0,1740^{*}$ \\
Usiminas & $0,1920^{*}$ & 0,1818 & $-0,4570$ & $-0,0197$ & $-0,1035$ & 0,0769 & 0,0631 \\
Vale & 0,0213 & 0,0402 & $-0,0713$ & $0,2286^{*}$ & $-0,0383$ & $-0,0301$ & 0,1312 \\
\hline
\end{tabular}

${ }^{*}$ denotes significance at the $1 \%$ level

Table $13-I N_{p}$ correlation between assets with medium and low liquidity in 2008

\begin{tabular}{|l|c|c|c|c|c|c|c|}
\hline & Caf Brasília PN & Sergen PN & Tupy ON & Excelsior PN & Hercules PN & Hoteis Otton & Marisol PN \\
\hline Comgás & $-0,0175$ & $-0,0488$ & $-0,1347$ & 0,0830 & $-0,0983$ & 0,0562 & 0,0029 \\
TAM & 0,0375 & 0,0486 & 0,1814 & 0,1488 & $-0,0468$ & 0,1031 & $-0,0995$ \\
MMX & $-0,0974$ & 0,0861 & $-0,1722$ & $-0,0782$ & 0,0837 & $-0,1063$ & $-0,0689$ \\
Celesc & $-0,0342$ & $-0,0503$ & 0,1044 & $-0,0029$ & 0,0993 & $-0,0394$ & $-0,0426$ \\
OHL & 0,0217 & 0,1381 & $-0,2150$ & 0,1542 & 0,0435 & 0,0692 & $0,1988^{*}$ \\
Porto Seguro & 0,0729 & 0,0525 & 0,0738 & 0,1380 & $-0,1081$ & $0,1569^{+}$ & 0,0566 \\
Randon & $-0,0556$ & 0,1999 & $-0,0826$ & 0,1333 & $-0,0790$ & 0,0006 & 0,0458 \\
Copasa & $-0,0690$ & $-0,0324$ & 0,0022 & $-0,0501$ & $-0,0901$ & $-0,0760$ & 0,0412 \\
Marcopolo & $0,3012^{*}$ & 0,1878 & 0,4497 & 0,1402 & $-0,1115$ & $0,3034^{*}$ & $-0,0090$ \\
Klabin & $-0,0021$ & 0,0394 & 0,1498 & $-0,1196$ & $-0,1238$ & 0,0281 & $-0,0629$ \\
\hline
\end{tabular}

*denotes significance at the $1 \%$ level

The data show that in 2007 and 2008, 88\% and $84 \%$ of cases have no correlation at a $1 \%$ level of significance. Therefore, there is evidence that there is no correlation between the trading of assets in accordance with $I N_{P}$.

\subsection{Markov Chain Portfolio Liquidity}

All portfolios are formed to be sold one day. Thus, it is reasonable to assume that portfolios with different quantities and qualities of assets experience different difficulties when they come to be sold. Portfolio $A$, consisting of a single stock, is likely to face less selling difficulty than Portfolio $B$, comprising 1,000 different shares including the stock of Portfolio $A$. Therefore, the liquidity of a portfolio in terms of selling all of its assets should incorporate the individual conditions of liquidity of each asset. In addition, the complete liquidation of a portfolio or a single stock has a dynamic characteristic, it may occur after several consecutive attempts (consecutive trading orders) over a period of time. What remains is to define an appropriate way of measuring the liquidity of a portfolio, it being understood that liquidity is the ease with which the whole portfolio is traded. 
INDEPENDENT JOURNAL OF MANAGEMENT \& PRODUCTION (IJM\&P)

http://www.ijmp.jor.br

v. 5, n. 2, February - May 2014.

ISSN: $2236-269 X$

DOI: 10.14807/ijmp.v5i2.156

Initially, consider two portfolios, $A$ and $B$, with two assets in each one. The probabilities of trading these assets are, respectively, $P_{1}$ and $P_{2}$. These probabilities can be obtained from past observations that associate the quality of these assets to the amounts traded, or by a subjective estimate originating from the intuition of experts. The random variable $X_{i}$ represents the possibility of trading of portfolio at time $i$ with $i=1,2,3, \ldots . n$. Assuming that $X_{i}$ are independent events and the probabilities remain the same throughout the $n$ attempts in the portfolio, then, from the viewpoint of Markov stochastic processes there are two possible states for the portfolio: (i) $S_{1}$, the portfolio is full (complete), or (ii) $S_{2}$, the portfolio is empty (sold or traded). Figure 1 below shows the state diagram of this situation.

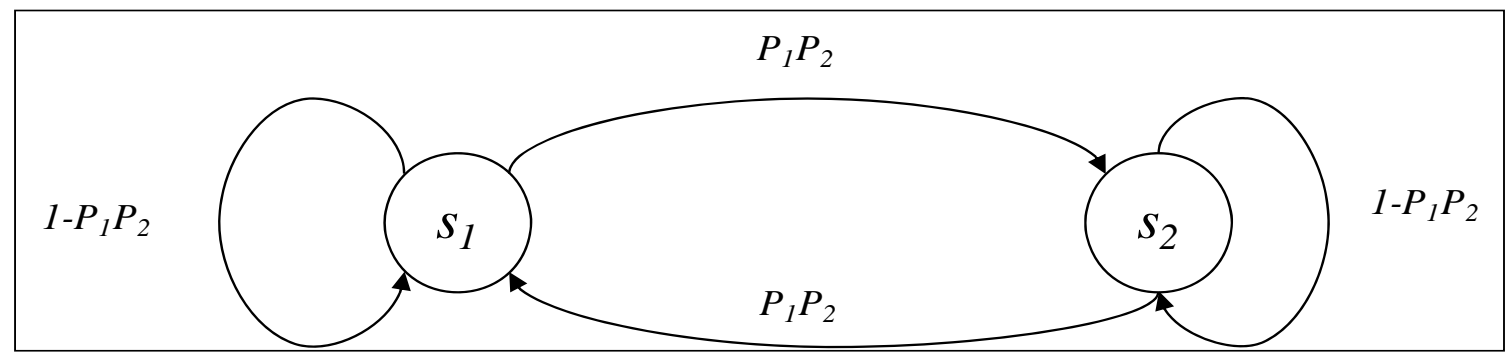

Figure 1 - State diagram of the negotiation portfolio comprising two assets

A question arises about the scenario shown: what is the probability of negotiating the portfolio after $n$ attempts?

The stability condition of the Markov chain requires that the transition probabilities are for $n=1,2, \ldots$, and all known possible sequences of states $s_{1}, s_{2}, s_{3}$ $, \ldots, s_{n+1}$ with $X_{n}, X_{n-1}, \ldots, X_{1}$ are given by:

$P\left(X_{n+1}=s_{n+1} / X_{1}=s_{1}, X_{2}=s_{2}, \ldots, X_{n}=s_{n}\right)=P\left(X_{n+1}=s_{n+1} / X_{n}=s_{n}\right)$

The respective transition matrix of the examined case of a portfolio with two assets would be:

$S_{1} \quad S_{2}$

$\left(\begin{array}{ll}\mathbf{p}_{11} & \mathbf{p}_{12} \\ \mathbf{p}_{21} & \mathbf{p}_{22}\end{array}\right)=\left(\begin{array}{cc}1-\mathbf{p}_{11} \mathbf{p}_{12} & \mathbf{p}_{11} \mathbf{p}_{12} \\ \mathbf{p}_{11} \mathbf{p}_{12} & 1-\mathbf{p}_{11} \mathbf{p}_{12}\end{array}\right) \quad \sum_{j=1}^{k} p_{i j}=1 \quad i=1,2, \ldots$

$$
p_{i j} \geq 0
$$

Similarly, the transition matrix of a portfolio of $n$ assets would be: 


$$
\left(\begin{array}{ll}
\mathbf{p}_{11} & \mathbf{p}_{12} \\
\mathbf{p}_{21} & \mathbf{p}_{22}
\end{array}\right)=\left(\begin{array}{cc}
1-\prod_{i=1}^{n} \mathbf{p}_{i} & \prod_{i=1}^{n} \mathbf{p}_{i} \\
\prod_{i=1}^{n} \mathbf{p}_{i} & 1-\prod_{i=1}^{n} \mathbf{p}_{i}
\end{array}\right) \quad \sum_{j=1}^{k} p_{i j}=1 \quad i=1,2, \ldots
$$

Using matrix calculations and the notion of Markov stochastic processes, the probability of trading a portfolio of $n$ assets after two attempts starting from an empty position is given by:

$$
P_{12}{ }^{2}=\left(\begin{array}{rr}
1-\prod_{i=1}^{n} P_{i} & \prod_{i=1}^{n} P_{i} \\
\prod_{i=1}^{n} P_{i} & 1-\prod_{i=1}^{n} P_{i}
\end{array}\right)\left(\begin{array}{rr}
1-\prod_{i=1}^{n} P_{i} & \prod_{i=1}^{n} P_{i} \\
\prod_{i=1}^{n} P_{i} & 1-\prod_{i=1}^{n} P_{i}
\end{array}\right)=\left(\begin{array}{rl}
\left(1-\prod_{i=1}^{n} P_{i}\right)^{2}+\left(\prod_{i=1}^{n} P_{i}\right)^{2} & 2\left(\prod_{i=1}^{n} P_{i}\right)\left(1-\prod_{i=1}^{n} P_{i}\right) \\
2\left(\prod_{i=1}^{n} P_{i}\right)\left(1-\prod_{i=1}^{n} P_{i}\right) & \left(1-\prod_{i=1}^{n} P_{i}\right)^{2}+\left(\prod_{i=1}^{n} P_{i}\right)^{2}
\end{array}\right)
$$

Based on the concepts of a finite Markov chain after $n$ trials, there is the possibility of the convergence of the probability matrix to state of equilibrium (since at least one $P_{i}<1$ ). The probabilities of this state are obtained by solving a linear system of equations. For the case analyzed of a matrix with two states, the probabilities $\pi_{1}$ and $\pi_{2}$ of liquidating the portfolio at the state of equilibrium would be obtained by solving the following system of equations (TAHA, 2008)

$(\pi 1, \pi 2)\left(\begin{array}{cc}\mathbf{1}-\prod_{\mathbf{i}=1}^{\mathbf{n}} \mathbf{P}_{\mathbf{i}} & \prod_{\mathbf{i}=1}^{\mathrm{n}} \mathbf{P}_{\mathbf{i}} \\ \prod_{\mathbf{i}=1}^{\mathrm{n}} \mathbf{P}_{\mathbf{i}} & \mathbf{1}-\prod_{\mathbf{i}=1}^{\mathrm{n}} \mathbf{P}_{\mathbf{i}}\end{array}\right)$

$\pi_{1}+\pi_{2}=1$

Assuming $\prod_{i=1}^{n} P_{i} \neq 0$, then, $\pi_{1}=\pi_{2}=0,5$

The number of iterations to reach each of the states of equilibrium would be $1 / \pi_{1}=1 / \pi_{2}=20$. Figure 2 shows an example of the convergence of the probability of trading a portfolio with two stocks with a general trading probability of 0.90 . As expected, according to the theory of Markov chains, the final state is quite different from the initial condition. 


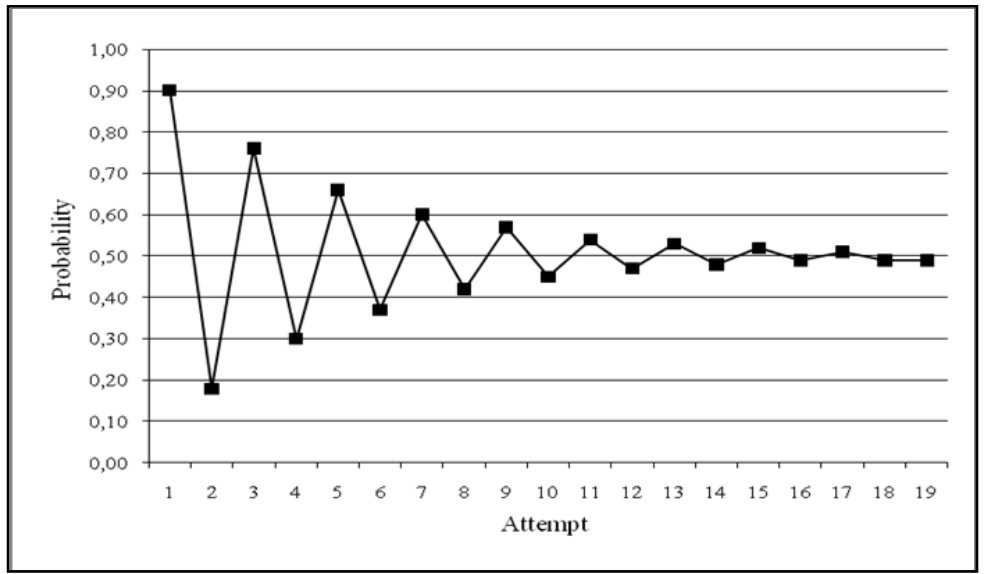

Figure 2 - Probability of the portfolio after $n$ attempts

\section{THE MARKOWITZ MODEL}

The approach developed by Markowitz (1952) assumes that the expected returns of the examined assets are known and so the allocation of available capital is possible. He suggests the use of past observations as an alternative to projecting expected returns.

$R_{i}$ is a random variable representing the rate of return per period of asset $i$ with $i=1,2,3,,,$, , and $X_{i}$ is the amount of capital to be invested in asset $i$. The expected return of the investment for the analyzed period is given by:

$$
r\left(x_{1}, x_{2}, \ldots . ., x_{n}\right)=E\left[\sum_{i=1}^{n} R_{i} x_{i}\right]=\sum_{i=1}^{n} E\left[R_{i}\right] x_{i}
$$

The duality return-risk is characterized by the expectation the investor has of obtaining maximum return for minimum risk. The risk measure used was the standard deviation of returns in a given period:

$$
\sigma\left(x_{1}, x_{2}, \ldots . ., x_{n}\right)=\sqrt{E\left[\left\{\sum_{i=1}^{n} R_{i} x_{i}-E\left[\sum_{i=1}^{n} R_{i} x_{i}\right]\right\}^{2}\right]}
$$

One interpretation of the Markowitz model as a quadratic programming problem is given by Konno and Yamazaki (1991): 
$\min Z=\sum_{i=1}^{n} \sum_{j=1}^{n} \sigma_{i j X i X_{j}}$

subject to:

$\sum_{i=1}^{n} r_{i} x_{i} \geq \rho M_{0}$

$\sum_{i=1}^{n} x_{i}=M_{0}$

$0 \leq x_{i} \leq u_{i}, \quad i=1,2, \ldots, n$

Where $M_{0}$ is the total available capital for investment, $\rho$ is the minimum rate of return desired by the investor, $\mu_{i}$ is the maximum amount of money that can be invested in asset $i, R_{i}=E\left[R_{i}\right]$ and $\sigma_{i j}=E\left[\left(R_{i}-r_{i}\right)\left(R_{j}-r_{j}\right)\right]$.

\section{THE PROPOSED MODEL}

The proposed approaches adopt the same assumptions as Markowitz model, plus the liquidity condition, based on Markov chains. The nonlinear models proposed aim to form a portfolio that simultaneously, minimize risk and maximize liquidity, after $k$ sequential attempts of trading, exceeding a minimum rate of return and deducting the operating costs of trading $(\alpha)$. The risk of the proposed optimization model $\left(P_{1}\right)$ is based on the covariance matrix of Markowitz.

The objective function was developed using the concept of goal programming (Hillier and Lieberman, 2005). The risk goal $\left(R_{g}\right)$ used was a small value, but close to zero (eg: 0.1). A natural candidate for the liquidity goal is the probability at the state of equilibrium explained in equation $16\left(\pi_{e}=0.5\right)$.

The model incorporates real practices of the financial market such as fees, taxes and dividend payments there by making them more realistic. Besides these features the following assumptions are made:

a) The planning horizon of the investor is the short term;

b) The planning horizon consists of a single continuous period;

c) The investor is risk averse, so, the higher the risk the higher the expected return;

d) Variable and fixed operating costs were considered.

Model P1 
$\min Z=\left|\frac{\sum_{i=1}^{n} \sum_{j=1}^{n} \sigma_{i j} X_{i} X_{j}-R_{g}}{R_{g}}\right|+\left|\frac{P^{(k)}-\pi_{e}}{\pi_{e}}\right| \quad$ (minimizes risk and maximizes liquidity)

subject to:

$\sum_{i=1}^{n} r_{i} x_{i}(1-\alpha) \quad(1-\lambda)+D_{i}-C_{i} \geq \rho M_{0} \quad$ (profitability is greater than benchmark)

$\sum_{i=1}^{n} x_{i}-C_{i}=M_{0}(1-\alpha)$

(allocated value is equal to initial investiment less cost)

$x_{i} \geq u_{i}$ (invested value per stock is greater than last negotiated value)

$\sum_{j=1}^{k} p_{i j}=1 \quad i=1,2, \ldots k$ (the sum of probabilities is equal to 1 )

$p_{i j} \geq 0$ (positive probability)

$x_{i} \geq 0 \quad i=1,2, \ldots ., n$

$y_{i} \in\{0,1\}$

Metaheuristics are powerful search engines inspired by models of human life or nature. They can achieve good solutions in a short computational time for problems that have no exact mathematical solution. Metaheuristics are more complex simulations that have the ability to incorporate patterns of human behavior during the simulation process, such as adaptation and learning, allowing for the selection of superior solutions. For this reason, some metaheuristics are considered to be artificial intelligence (e.g.: genetic algorithms). Examples of metaheuristics: (i) Genetic Algorithms (GA), (ii) Ant System, (iii) Tabu Search, (iv) Simulated Annealing (SA) and (v) Hybrids. Financial decisions in the short term, such as the portfolio, are inserted in the context of optimization.

Genetic Algorithms were chosen as search engine to select the best combination of stocks for the portfolio by the proposed model. In GA, the term chromosome typically refers to a candidate solution. Functionally, the genetic algorithm uses the following operators (Holland, 1975):

a) Reproduction

The initial solution is formed by a sequence of bits that represent the characteristics of the product. The selection operator selects a subset of $m$ chromosomes of size $M$ of the population that can reproduce, on average, better adapted chromosomes produce more offspring than the less well adapted. Generally, the size of the chromosome is maintained in successive generations.

b) Crossover 
INDEPENDENT JOURNAL OF MANAGEMENT \& PRODUCTION (IJM\&P)

http://www.ijmp.jor.br

v. 5, n. 2, February - May 2014.

ISSN: $2236-269 X$

DOI: 10.14807/ijmp.v5i2.156

The operator of the crossover exchange parts of chromosomes positions specifically chosen for the formation of new offspring.

c) Mutation

The mutation operator changes the values of some attributes at random.

\section{RESULTS}

Liquidity was estimated by weighting the frequency $F$ obtained by dividing the trading days of each action in period $\left(F_{a}\right)$ by the number of trading days in the period $\left(F_{p}\right)\left(F=F_{a} / F_{p}\right)$. This frequency was weighted by its respective average IN divided by the maximum number recorded between the studied securities $\left.\left(F x I N_{\text {avg }} / I N_{\text {max }}\right)\right)$. The weighted ratio was grouped into quartiles arbitrarily assuming, the average probability of $1,2,3$ and 4 , respectively, $1.00,0.75,0.50$ and 0.05 . This was the possible liquidity estimate that could be obtained from the public data available. The list of shares participating in the simulations with their respective quartiles and trading probabilities are presented in Table 14 below.

The Brazilian financial market defines the validity of a buy or sell order by the number of days and not by the number of attempts. Twenty attempts were adopted as an intermediate value between the minimum and maximum used by the market.

As suggested by Markowitz (1952), for demonstration purposes, the average performance of the $1^{\text {st }}$ half of 2009 was used to estimate the profitability of each stock.

Table 14 - List of stocks and probabilities

\begin{tabular}{clccclcc}
\hline Ranking & Stock & Probability & Quartil & Ranking & Stock & Probability & Quartil \\
\hline 1 & Ambev & 0.75 & 3 & 14 & MMX & 0.50 & 2 \\
2 & Bradesco & 0.75 & 3 & 15 & Celesc & 0.50 & 2 \\
3 & Banco do Brasil & 1.00 & 4 & 16 & OHL & 0.50 & 2 \\
4 & CESP & 0.75 & 3 & 17 & P. Seguro & 0.50 & 2 \\
5 & Gerdau & 1.00 & 4 & 18 & Random & 0.50 & 2 \\
6 & Net & 1.00 & 4 & 19 & Copasa & 0.75 & 3 \\
7 & Petrobras & 1.00 & 4 & 20 & Marco & 0.75 & 3 \\
& & & & & Polo & & \\
8 & CSN & 1.00 & 4 & 21 & Klabin & 1.00 & 4 \\
9 & Telemar & 0.50 & 2 & 22 & Caf Brasil & 0.05 & 1 \\
10 & Usiminas & 1.00 & 4 & 23 & Sergen & 0.05 & 1 \\
11 & Vale & 1.00 & 4 & 24 & Hercules & 0.05 & 1 \\
12 & Comgás & 0.50 & 2 & 25 & Marisol & 0.05 & 1 \\
13 & TAM & 0.75 & 3 & & & & \\
\hline
\end{tabular}

Once the portfolio is classified in terms of attributes and levels, an initial population of size $M$ is randomly generated. For purposes of this research, a convergence was found with the following configuration parameters of genetic 
INDEPENDENT JOURNAL OF MANAGEMENT \& PRODUCTION (IJM\&P)

http://www.ijmp.jor.br

v. 5, n. 2, February - May 2014.

ISSN: 2236-269X

DOI: $10.14807 /$ ijmp.v5i2.156

algorithm: (i) $M=52 ; \quad$ (ii) a uniform rate of crossover equal to $50 \%$; (iii) a mutation rate of $10 \%$, (iv) stopping criterion after 75,000 iterations and (v) the Evolver ${ }^{\circledR}$ internal method recipe. The best results and comparisons between the models are shown in Table 15 below. Figure 3 below shows the evolution of the variation in the profitability of the portfolios (Markowitz and P1) during the period June to December 2009.

\begin{tabular}{|c|c|c|c|}
\hline Indicators & Markowitz & P1 & Ibovespa \\
\hline \# stocks & 6 & 6 & 65 \\
\hline Stocks & $\begin{array}{c}6-8-18 \\
19-22-23\end{array}$ & $\begin{array}{l}2-3-4- \\
1619-20\end{array}$ & \\
\hline Estimated & & & \\
\hline $\begin{array}{l}\text { Profitability } \\
\text { Observerd }\end{array}$ & $4.26 \%$ & $4.63 \%$ & $4.20 \%$ \\
\hline Profitability ${ }^{5}$ & $4.75 \%$ & $5.69 \%$ & $4.90 \%$ \\
\hline Risk ( $\beta$ ) & 0.2601 & 0.6937 & $1.0000^{6}$ \\
\hline Liquidity (Markov) & 0.0184 & 0.4998 & $1.0000^{6}$ \\
\hline
\end{tabular}

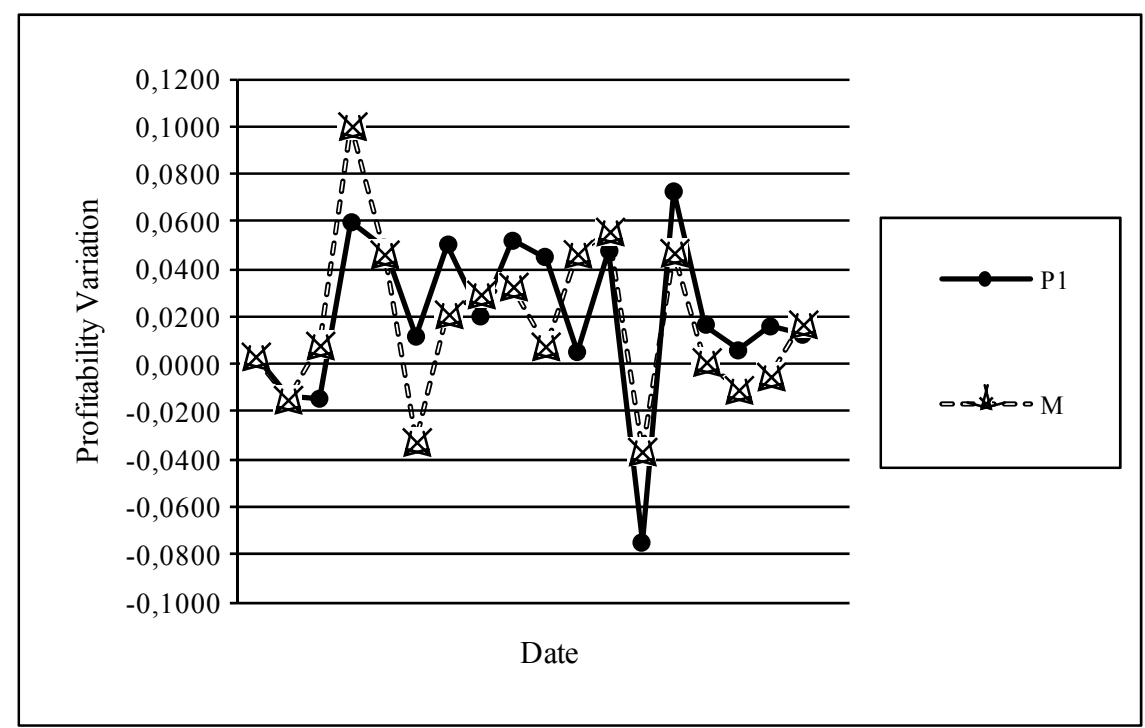

Figure 3 - Portfolio profitability evolution

As expected, the Markowitz model created portfolio with lower volatility (0.2601) relative to the Ibovespa market portfolio according to $\beta$ Sharpe. The proposed model, in turn, have created high volatile portfolio $(0.6937)$, however, the difference in quality of the selected assets is significant. The Markowitz model 
INDEPENDENT JOURNAL OF MANAGEMENT \& PRODUCTION (IJM\&P)

allocated values to shares 22 and 23 that have low liquidity while the proposed model $\mathrm{P} 1$, as expected, avoided selecting these assets.

The share of less liquid stocks (22 and 23) in portfolio of Markowitz reduced the potential returns of the portfolio because of lower trading frequency of trading and the updating of their prices at auctions. The portfolio formed by the P1 model, incorporated the most liquid stocks and is more realistic in terms of potential trading shares and include well know Brazilian companies such as Bradesco and Marco Polo.

\section{FINAL CONSIDERATIONS}

The multi-criteria optimization model generated in this study incorporated an innovative measure of liquidity based on the probability of trading the shares included in a stochastic process of Markov chains. This includes two important aspects: (i) an approach to the dynamism of a market that trades shares in several attempts, and (ii) the introduction of liquidity and transaction costs in the decisions. The work reinforced the conclusion obtained in other studies that the absence of transaction costs can generate inefficient or unrealistic portfolios.

This study considered two possible states of negotiation (negotiated or not negotiated). However, other states of the partial liquidation of the portfolio could be simulated, but this would require a large computational effort for implementing. This opens the way to new lines of research on the subject.

\section{REFERENCES}

AMIHUD, Y.; MENDELSON, H. (1991). Liquidity, Asset Prices and Financial Policy. Financial Analysts Journal, v. 47, n. 6, p. 56-66.

ARNOTT, R. D.; WAGNER, W. H. (1990). The Measurement and Control of Trading Costs. Financial Analysts Journal, v. 46, n. 6, p. 73-80.

BANZ, R. W. (1981). The Relationship between Return and Market Value of Common Stocks. Journal of Financial Economics, v. 9, n. 1, p. 3-18.

BAUERLE, N.; RIEDER, N. (2004). Portfolio Optimization with Markov Modulated Stock Prices and Interest Rates. IEEE Transactions on Automatic Control, v. 49, n. 3, p. 442-447.

BMF\&Bovespa. Daily Bulletin of Business. Available: http://www.bovespa.com.br. Access: 16 September 2012

CAKMAK, U.; OZEKICI, S. (2006). Portfolio Optimization in Stochastic Markets, Mathematical Methods of Operations Research, v. 63, n. 1, p. 151-168. 
INDEPENDENT JOURNAL OF MANAGEMENT \& PRODUCTION (IJM\&P)

http://www.ijmp.jor.br

v. 5, n. 2, February - May 2014.

ISSN: $2236-269 X$

DOI: 10.14807/ijmp.v5i2.156

COSTA, O. L. V.; ARAUJO, M. V. (2008). A Generalized Multi-period Mean Variance Portfolio Optimization with Markov Switching Parameters. Automatica, v. 44, n. 10, p.2487-2497.

FAMA, E. F.; FRENCH, K. R. (1992). The Cross-section of Expected Stock Returns. Journal of Finance, v. 47, n. 2, p. 427- 465.

GOYENCO, R. Y.; HOLDEN, C. W.; TRZCINKA, C. A. (2009). Do Liquidity Measures Measure Liquidity? Journal of Financial Economics, v. 92, n. 2, p. 153-181.

HESTON, S. L.; SADKA, R. (2008). Seasonability in the Cross-Section of Stock Returns. Journal of Financial Economics, v. 87, n. 2, p. 418-445.

HILLIER, F. S.; LIEBERMAN, G. J. (2005). Introduction to Operations Research. Columbus: McGraw-Hill.

HOGAN, S. (2004). Testing Market Efficiency using Statistical Arbitrage with Applications to Momentum and Value Strategies. Journal of Financial Economics, v. 73 , n. 3 , p. 525-564.

HOLLAND, J.H. (1975). Adaptation in Natural and Artificial Systems. Ann Arbor: The University of Michigan Press.

JANA, P.; ROY, T. K.; MAZUMDER, S. K. (2009). Multi-objective possibilistic Model for Portfolio Selection with Transaction Cost. Journal of Computational and Applied Mathematics, v. 228, n. 1, p. 188-196.

KONNO, H.; YAMAZAKI, H. (1991). Mean-absolute Deviation Portfolio Optimization Model and its Applications to Tokio Stock Market. Management Science, v. 37, n. 5, p. 519-531.

LESMOND, D. A. (2005). Liquidity of Emerging Markets. Journal of Financial Economics, v. 77, n. 2, p. 411-452.

LEWELLEN, J. (2006). The Conditional CAPM does not Explain Asset-Pricing Anomalies. Journal of Financial Economics, v. 82, n. 2, p. 289-314.

MARKOWITZ, H. (1952). Portfolio Selection. Journal of Finance, v. 7, n. 1, p. 77-91.

PARRA, M. A.; TEROL, B.; URIA, M. V. R. (2001). A Fuzzy Goal Programming Approach to Portfolio Selection. European Journal of Operational Research, v. 133 , n. 2, p. 287-297.

PAULA LEITE, H.; SANVINCENTE, A. Z. (1995). Índice BOVESPA: Um Padrão para os Investimentos Brasileiros. São Paulo: Atlas.

POGUE, G. A. (1970). An Extension of the Markowitz Portfolio Selection Model to Include Variable Transactions' Costs, Short Sales, Leverage Policies and Taxes. Journal of Finance, v. 25, n. 5, p. 1005-1027.

REBOREDO, J. C. (2002). Bank Solvency Evaluation with a Markov Model. Applied Financial Economics, v. 12, n. 5, p. 337-345.

ROSS, A. S.; WESTERFIELD, R.W.; JAFFE, J. F. (1999). Corporate Finance. Columbus: McGraw-Hill.

SHARPE, W. (1964). Capital Asset Prices: A Theory of Market Equilibrium under Conditions of Risk. Journal of Finance, v. 19, n. 3, p. 425-442.

TAHA, H. A. (2008). Operations Research: an Introduction. New York: Prentice Hall. 
INDEPENDENT JOURNAL OF MANAGEMENT \& PRODUCTION (IJM\&P)

http://www.ijmp.jor.br

v. 5, n. 2, February - May 2014.

ISSN: 2236-269X

DOI: 10.14807/ijmp.v5i2.156

YOUNG, M. R. (1998). A Minimax Portfolio Selection Rule with Linear Programming Solution. Management Science, v. 44, n. 5, p. 673-683. 